\title{
Corporate Social Responsibility in India
}

\section{* Dr. A. K. Singh}

\section{Abstract}

The external environment of business has undergone revolutionary changes which generated far-reaching impact on organizational performance and their management strategies. With globalization and liberalization of economy, issues like the changing desires and attitudes of customers, the requirement of government agencies, rapidly advancing technology, increasing cost of production, increased awareness towards environmental protection and sustainable development, rapidly changing political scenario, have emerged as issues of importance which corporate sector cannot ignore. These issues affect the organizations and management intensively. The philosophy of 'Bottom of the Pyramid' advocated by Management Guru late Prof. C.K. Prahlad gained momentum in the context of changed business environment and social responsiveness of corporate houses. Milton Friedman viewed that business should produce goods and services efficiently and leave the solution of social problems to government, concerned organizations and individuals. However, Keith Davis is of the view that there is an iron law of responsibility which states that in the long-run those who do not use power in a manner that society considers responsible will tend to lose it. Thus, it was advocated by the management experts that business organizations must devote resources to socially desirable objectives besides making profits to maintain the confidence and support of its stakeholders and creditors. CSR can generate values and create opportunities for corporate houses for enhancing their business performance and building strongly relations with the stakeholders and community. Against this backdrop, present paper purports to examine the growth and development of CSR in India.

Keywords: CSR, Public Sector, Private Sector, BSE

* Assistant Director, Regional Centre for Urban and Environmental Studies , Lucknow University, Lucknow 


\section{Introduction}

The concept of Corporate Social Responsibility has been in vogue for quite some time in the business world, though its origin can be traced back to olden times. The CSR has been defined differently over the years and no single definition has been universally accepted so far. Its roots can be traced back to all the philanthropic activities of the corporate houses and individuals across the globe. Its concept has evolved globally and at the moment, it encompasses all related concepts of Triple Bottom Line, Corporate Citizenship, Philanthropy, Strategic Philanthropy, Shared Value, Corporate Sustainability and Business Responsibility. Some of the prominent definitions have been cited hereunder to illustrate the point. Corporate Social Responsibility is "the responsibility of the enterprise for their impact on society" To completely meet their social responsibility the enterprises "should have in place a process to integrate social, environmental, ethical, human rights, and consumer's concerns into business operations and core strategy in close cooperation with their stake-holders. Another significant definition depicts CSR as "the continuing commitment by business to contribute to economic development while improving the quality of life of workforce and their families as well as of community and society at large."Still another definition proclaims CSR as "a management concept whereby companies integrate social and environmental concerns in their business operations in interactions with their stakeholders". Thus CSR is generally understood as being the way through which a company achieves the balance of economic environmental and social imperatives while at the same time addressing the expectations of shareholders. In this sense it is important to draw a distinction between a CSR which can be strategic business management concept and charity sponsorship or philanthropy. Even though the latter can also make valuable contribution to reduction of poverty, enhancing directly the reputation of the company, and strengthening its brand, the concept of CSR entails beyond that.

The CSR campaign has been actively supported by the world 
organizations like World Bank, UNDP, OECD, European Commission and MNCs. It has risen to the top on the agenda of policy makers, managers and activists in the recent past. The European Multi Forum, an outgrowth of the 2000 Lisbon Summit adopted CSR in its final report. The CSR in India has traditionally been seen as a philanthropic activity since times immemorial. It was undertaken by the individuals, business houses, and kings but never was deliberated upon. Therefore not much has been documented naturally, on the concept of CSR and its activities. However it was always found engrained in the national character which guided and goaded people to contribute extensively and intensively to the national freedom struggle. Still today, the practice of CSR remains basically philanthropic but now it has move on from nation and institution building to community development with global influences. With communities becoming more active and demanding, there appears a discernible trend of the CSR remaining largely restricted to community development on one hand, it is getting more strategic in nature than philanthropic activities on the other. A large number of companies now report the CSR activities that they undertake in their official website, annual reports and even CSR reports. In India J. R. D. Tata was personally enthusiastic about all the aspects of labour welfare including family planning in the pre- independence period. The Tata Group introduced he notion of minimum wage, provident fund, insurance, old age pension, housing, health care, education etc. Since then quite a few CSR initiatives have been successfully in operation. The Indian Companies Act, 2013 has introduced the CSR idea to the forefront in the country and through it explains the mandate in promoting greater transparency and disclosure. The Schedule 7 of the Act listing the CSR activities, suggests the communities to be focal point. On the other hand, by discussing a company's relationship to its stake-holders and integrating CSR into its core operations, the Draft Rules suggest that CSR needs to go beyond communities and also beyond philanthropy. It would be quite interesting to observe and study how it translates into practice at ground level and also how the understanding of the CSR in India undergoes a change. The recent initiatives of the present Government 
at the Centre seems certainly encouraging. It has directed its public sector undertakings to earmark certain percentage of their annual budget for the furtherance of the CSR activities. A Panel of Expert has also been constituted recently to suggest the framework to assess CSR activities undertaken by the companies under the Indian Companies act, 2013.

The importance of Corporate Social Responsibility (CSR) has emerged significantly in the last two decades. During this period owing to a surge in the transnational trade and globalization, CSR has gained immense popularity (Mirshak et.al, 2007). "Corporate Social Responsibility has been defined as the commitment by business to contribute to social and economic development through improving the quality of life of the workforce and their families besides development of community and society at large"(World Business Council for Sustainable Development, 1999). Many firms engaging in CSR take up environmental, social and other activities that promote stakeholders' well-being. Activities associated with CSR are always debatable on the context of enhancement of the firm's social performance in relation to the additional expenses incurred (Nelling et.al. 2009). Though few researchers maintain that businesses engaged in CSR practices are profitable (Porter and Kramer, 2002), yet some do not see any kind of relationship between business profitability and CSR (Aupperle et al. 1985). A difference of opinion amongst the researchers makes the study of the relationship between the economic accomplishments of the firms and CSR a focal point, specifically as most of the firms give emphasis to financial growth (Pinkston et. al., 1996).

\section{Legal Framework}

The first formal attempt by the Government of India to put the CSR issue on the table was in the issuance of Corporate Social Responsibility Voluntary Guidelines in 2009 by the Ministry of Corporate Affairs (MCA, 2009). Even earlier the importance of CSR was discussed in the context of corporate governance reforms, e g. the Report of the Task Force on Corporate Excellence by the Ministry of Corporate Affairs (MCA, 2000). The Guidelines specifically drew a 
distinction between philanthropy and CSR activities, and highlighted the voluntary nature of CSR activities that go beyond any statutory or legal obligation. These Guidelines (2009) were followed in 2011 by the National Voluntary Guidelines of Social, Environmental \& Economic Responsibilities of Business, issued by the Ministry of Corporate Affairs (MCA, 2011). These were reportedly based on the inputs received from 'vital stakeholders' across the country and laid down nine principles for businesses to function in a responsible manner to promote inclusive economic growth at the national level.

The most ambitious attempt at mandated CSR activities for companies came with the enactment of Section 135 of the Companies Act 2013 (MCA, 2013). As stated earlier in the Introduction part of this paper, Section 135 made CSR spending as well as reporting mandatory for the very first time and brought the CSR activities of Indian corporates under the purview of Corporate Law. Specifically, the provisions under Section 135 require companies with net worth of rupees five hundred crore or more, or turnover of rupees one thousand crore or more or a net profit of rupees five crore or more (i) to appoint a CSR Committee of at least 3 directors (one independent director), and (ii) under the guidance of the CSR Committee, spend in every financial year, at least two per cent of the average net profits of the company made during the three immediately preceding financial years, in pursuance of its Corporate Social Responsibility Policy. While the quantum of CSR spending along with reporting has been mandatorily set under Section 135, there is some inbuilt flexibility in the law in terms of a company's choice of its CSR activities. Instead of rigidly defining the boundaries of CSR, the Act broadly specifies in Annexure VII of the Act, the scope of social responsibility in terms of a list of activities that the corporates can potentially undertake, leaving the choice of activities to their discretion. So far as compliance to Section 135 is concerned, the law adopts a comply-orexplain approach, with no explicit penalties for non-compliance.

The New Companies' Act, 2013 has replaced the Company's Act, 1956 , an outdated framework of corporate governance that gave the Indian government a high degree of oversight into corporate 
management. The salient features of New Company's Act are as follows (MCA, 2013):

- Every company will have a uniform fiscal year running from April $1^{\text {st }}$ to March $31^{\text {st }}$ which matches with government's fiscal year.

- Publically traded firms and large private firms must rotate financial auditors every 5 or 10 years.

- Every publically traded firms and large private firms must have at least one female director on its Board of Directors.

- Publically traded firms and large private firms must ensure that $1 / 3^{\text {rd }}$ of the Board should constitute of independent directors.

- Publically traded firms must establish specific Board committees if they are not already established, including a Nomination and Compensation Committee, an Audit Committee and a Corporate Social Responsibility Committee.

- The Board of each company above a modest threshold must ensure that the company spends 2 per cent of its pre-tax profits on Corporate Social Responsibility activities, or specify the reasons why it did not meet this target in its annual report.

\section{CSR Spending}

Table No 1 : Voluntary Adoption and Disclosure of CSR by Listed Companies in India

\begin{tabular}{|c|c|}
\hline Year & $\begin{array}{c}\text { Percentage of Top 500 Listed Companies } \\
\text { Undertaking CSR }\end{array}$ \\
\hline 2003 & 7.53 \\
\hline 2004 & 14.61 \\
\hline 2005 & 23.42 \\
\hline 2006 & 27.81 \\
\hline 2007 & 33.84 \\
\hline 2008 & 42.39 \\
\hline 2009 & 51.76 \\
\hline 2010 & 52.12 \\
\hline 2011 & 62.18 \\
\hline
\end{tabular}

Source: IGIDR, 2015 
Table No 1 presents the year-wise percentage of listed corporates that have voluntarily adopted CSR and reported it. The striking feature is that the percentage of large listed companies that have engaged and reported CSR has steeply risen from just around 7 per cent to around 62 per cent. Additionally, there has been significant increase in the incidence of CSR, particularly in the early years when there was no pro-active CSR policy of the government, with the upward trend continuing post 2009 after the first set of voluntary guidelines was issued and CSR was formally introduced in the Companies Bill, 2009.

The distribution of companies by the number of distinct CSR activities they engage in is presented in Table No 2. As is evident from the Figure, companies choose to focus on a small number of CSR activities with one third of them focusing on only one activity and around 78 per cent engaging in 3 or lesser activities. The estimates show that companies avoid spreading themselves too much, and perhaps choose activities which are built around their core business.

\section{Table No 2 : Distribution of Companies by Number of Distinct CSR Activities in India}

\begin{tabular}{|c|c|}
\hline Number of Activies & $\begin{array}{c}\text { Percentage of Top 500 Listed } \\
\text { Companies Undertaking CSR }\end{array}$ \\
\hline 1 & 32.47 \\
\hline 2 & 26.31 \\
\hline 3 & 19.99 \\
\hline 4 & 12.84 \\
\hline 5 & 5.77 \\
\hline 6 & 2.00 \\
\hline 7 & 0.56 \\
\hline 8 & 0.07 \\
\hline
\end{tabular}

Source: IGIDR, 2015

Distribution of type of CSR activities by companies is shown in Table No 3. Education, skill development/training and employment 
Table No. 3 : Distribution of Type of CSR Activities Undertaken by Companies

\begin{tabular}{|l|c|c|}
\hline \multicolumn{1}{|c|}{ Type of CSR Activity } & Frequency & Percentage \\
\hline Agriculture and Irrigation & 78 & 2.56 \\
\hline $\begin{array}{l}\text { Village, Rural Infrastructure and } \\
\text { Development }\end{array}$ & 246 & 8.06 \\
\hline $\begin{array}{l}\text { Food, Drinking Water, Sanitation and } \\
\text { Health }\end{array}$ & 514 & 16.84 \\
\hline $\begin{array}{l}\text { Education, Skill Development/ } \\
\text { Training and Employment }\end{array}$ & 542 & 17.76 \\
\hline Waste and Water Management & 54 & 1.77 \\
\hline Safety and Disaster Management & 161 & 5.28 \\
\hline Urban Development & 8 & 0.26 \\
\hline $\begin{array}{l}\text { Energy/Sustainability and } \\
\text { Environment }\end{array}$ & 433 & 14.19 \\
\hline $\begin{array}{l}\text { Aid (Infrastructure, Material Aid, } \\
\text { Financial Aid to NGOs) }\end{array}$ & 336 & 11.01 \\
\hline $\begin{array}{l}\text { Empowerment of Women/ People/ } \\
\text { Disablity/Old Age Care/Orphanage }\end{array}$ & 302 & 9.90 \\
\hline $\begin{array}{l}\text { Quality of Life/Improvement of } \\
\text { Working Conditions }\end{array}$ & 93 & 3.05 \\
\hline Arts, Sports and Culture & 90 & 2.95 \\
\hline Social Service and Awareness & 155 & 5.08 \\
\hline Miscellaneous & 1 & 0.03 \\
\hline Not Specified & 39 & 1.28 \\
\hline Source: & & \\
\hline SID/, & & \\
\hline
\end{tabular}

Source: IGIDR, 2015

constituted a large segment (17.76 per cent) while food, drinking water, sanitation and health accounted for 16.84 per cent. Energy/sustainability and environment (14.19 per cent) and infrastructure and financial aid to NGOs (11.01 per cent) accounted 
for other major activities during 2008.Presently, the thematic areas of Corporate Social Responsibility include education, health care, environment, livelihood development, and rural development. In education sector, corporates are interested in infrastructure support, scholarship, quality of education, girl child education, adult education, and running own schools and educational institutions. Health care sector of includes activities of organizing health camps, maternal and child health care, infrastructure and equipments support, water and sanitation while Environment sector includes activities of green initiatives, water conservation, and waste management. These activities in rural development and livelihoods sector include infrastructure support, awareness generation, and support of differently abled, youth clubs, skill development and income generation. The CSR activities are concentrates in Maharashtra, Orissa, Uttar Pradesh, Bihar, and Rajasthan. Majority of Corporates have partnership with NGOs for CSR activities.

CSR spending of top companies is shown in the Table No. 4 All of the 27 companies would come under the purview of Section 135 of new Companies Act, 2013. More than half of the companies have been spending less than 2 per cent on CSR, and 11 of them even less than one per cent. The amount of CSR spending was recorded highest in case of Lupin followed by Reliance and Tata Steel in 201213

Table No .4 : CSR Spending of Top Companies During 2012-13

\begin{tabular}{|l|c|c|c|c|c|}
\hline Company & $\begin{array}{c}\text { Paid Up } \\
\text { Capital } \\
\text { (Rs. } \\
\text { Crore) }\end{array}$ & $\begin{array}{c}\text { Total } \\
\text { Turn } \\
\text { Over (Rs. } \\
\text { Crore) }\end{array}$ & $\begin{array}{c}\text { Total } \\
\text { Profit } \\
\text { After Tax } \\
\text { (Rs. } \\
\text { Crore) }\end{array}$ & $\begin{array}{c}\text { Total } \\
\text { Spending } \\
\text { on CSR } \\
\text { (Rs. } \\
\text { Crore) }\end{array}$ & $\begin{array}{c}\text { Percenta } \\
\text { ge of } \\
\text { Total } \\
\text { Profit } \\
\text { After Tax }\end{array}$ \\
\hline CSR $>$ 2\% of Total Profit After Tax & & & \\
\hline $\begin{array}{l}\text { Tata } \\
\text { Motors } \\
\text { Ltd. }\end{array}$ & 638.07 & 49320 & 301.81 & 19.21 & 6.36 \\
\hline $\begin{array}{l}\text { J.P. } \\
\text { Associates }\end{array}$ & 1.18 & 13512.08 & 501.28 & 28.82 & 5.75 \\
\hline
\end{tabular}




\begin{tabular}{|l|r|r|r|r|r|}
\hline Tata Steel & 971.22 & 38199.43 & 5062.97 & 170.76 & 3.37 \\
\hline $\begin{array}{l}\text { Ambuja } \\
\text { Cement }\end{array}$ & 308.44 & 9674.94 & 1297.06 & 39.08 & 3.07 \\
\hline $\begin{array}{l}\text { Ultratech } \\
\text { Cement }\end{array}$ & - & - & - & - & 2.63 \\
\hline $\begin{array}{l}\text { Ranbaxy } \\
\text { Labs }\end{array}$ & 211.45 & 6112.44 & 162.34 & 4.27 & 2.62 \\
\hline $\begin{array}{l}\text { Grasim } \\
\text { Industries }\end{array}$ & 91.78 & 5689.58 & 1225.99 & 25.30 & 2.13 \\
\hline CSR 1-2\% of Total Profit After Tax & & & & \\
\hline ACC & 187.95 & 11130.45 & 1061.19 & 20.16 & 1.90 \\
\hline $\begin{array}{l}\text { Hindustan } \\
\text { Uniliver }\end{array}$ & - & - & - & - & 1.82 \\
\hline IDFC & 1514.72 & 8148.42 & 1836.00 & 30.00 & 1.70 \\
\hline $\begin{array}{l}\text { Reliance } \\
\text { Industries }\end{array}$ & 3229.00 & 371119.00 & 21003.00 & 375.05 & 1.71 \\
\hline $\begin{array}{l}\text { Lasen \& } \\
\text { Toubro }\end{array}$ & 123.08 & 61470.86 & 4910.65 & 73.16 & 1.49 \\
\hline Hindalco & 190.48 & 26056.93 & 1699.20 & 29.79 & 1.48 \\
\hline $\begin{array}{l}\text { ICICI } \\
\text { Bank }\end{array}$ & 1154.00 & 48421.00 & 8325.00 & 116.55 & 1.4 \\
\hline ITC Ltd & 790.18 & 41809.82 & 7418.39 & 82.34 & 1.1 \\
\hline SBI & 684.03 & 135691.94 & 14105.32 & 117.07 & 1.0 \\
\hline $\begin{array}{l}\text { Mahindra } \\
\text { and } \\
\text { Mahindra }\end{array}$ & 306.99 & 40990.33 & 3352.82 & 33.52 & 1.0 \\
\hline Sesa Goa & 86.91 & 2554.00 & 2280.00 & 22.59 & 1.0 \\
\hline CSR < 1\% of Total Profit After Tax & & & & \\
\hline Axis Bank & 467.95 & 33733.68 & 5179.43 & 42.42 & 0.81 \\
\hline $\begin{array}{l}\text { Asian } \\
\text { Paints }\end{array}$ & 95.92 & 8971.70 & 1050.00 & 0.98 & 0.09 \\
\hline
\end{tabular}




\begin{tabular}{|l|r|r|r|r|c|}
\hline $\begin{array}{l}\text { Bank of } \\
\text { Bardoda }\end{array}$ & 422.52 & 802069.12 & 4480.72 & 7.00 & 0.16 \\
\hline Cipla Ltd & 160.58 & 8294.58 & 1507.11 & 7.65 & 0.5 \\
\hline Lupin & 8951.00 & 707239.00 & 126043.00 & 937.00 & 0.74 \\
\hline $\begin{array}{l}\text { Cairn } \\
\text { India }\end{array}$ & 1910.23 & 17524.14 & 12056.39 & 20.86 & 0.17 \\
\hline $\begin{array}{l}\text { Hero } \\
\text { Motocorp }\end{array}$ & 39.94 & 24166.49 & 2118.16 & 1.39 & 0.06 \\
\hline $\begin{array}{l}\text { Kotak } \\
\text { Mahindra } \\
\text { Bank }\end{array}$ & 373.00 & 9203.00 & 1361.00 & 4.08 & 0.3 \\
\hline PNB & 353.47 & 700285.00 & 4747.52 & 3.24 & 0.07 \\
\hline $\begin{array}{l}\text { Tata } \\
\text { Power }\end{array}$ & 237.33 & 9567.28 & 1024.69 & 7.88 & 0.77 \\
\hline TCS & 295.72 & 50656.53 & 12786.34 & 65.21 & 0.51 \\
\hline
\end{tabular}

Source: IGIDR, 2015

Mandated CSR in India is shown in Table No 5. There has been decline in CSR spending as percentage of total social expenditure during 2010 to 2012. However, gross amount under CSR spending has significantly increased over the period. Total CSR spending was estimated Rs. 8343.9 crores during 2012 while it was recorded Rs. 7609.1 crore in 2010.

Table No 5 : Mandated CSR in India

\begin{tabular}{|l|c|c|c|}
\hline \multicolumn{1}{|c|}{ Indicators } & $\mathbf{2 0 1 2}$ & $\mathbf{2 0 1 1}$ & $\mathbf{2 0 1 0}$ \\
\hline Total BSE listed companies & 5138 & 5138 & 5138 \\
\hline $\begin{array}{l}\text { Total Number of Qualifying } \\
\text { Companies in terms of Section } \\
\text { 135 Criteria }\end{array}$ & 1372 & 1409 & 1500 \\
\hline $\begin{array}{l}\text { Total Qualifying Companies } \\
\text { with Profit After Tax }>0\end{array}$ & 1265 & 1312 & 1457 \\
\hline $\begin{array}{l}\text { Total Profit After Tax } \\
\text { Qualifying Companies with } \\
\text { Profit After Tax }>0 \text { (Rs. Crore) }\end{array}$ & 417198.6 & 383487.1 & 380453.1 \\
\hline
\end{tabular}




\begin{tabular}{|l|c|c|c|}
\hline $\begin{array}{l}\text { Total Estimated CSR Spending } \\
\text { of Qualifying Companies with } \\
\text { Profit After Tax > 0 (Rs. Crore) }\end{array}$ & 8343.9 & 7669.7 & 7609.1 \\
\hline $\begin{array}{l}\text { Total Social Expenditure of } \\
\text { Central and State Government }\end{array}$ & 617939.0 & 529398.0 & 446382.0 \\
\hline $\begin{array}{l}\text { CSR Spending as percentage of } \\
\text { Total Social Expenditure }\end{array}$ & 1.35 & 1.45 & 1.70 \\
\hline
\end{tabular}

Source: Economic Survey, 2012-13, Government of India

Estimated CSR spending by all BSE listed companies is shown in Table No.6. During 2012, 5138 BSE listed companies were reported. Out of them, 1372 companies were qualified in terms of Section 135 criteria. Maximum CSR was recorded Rs. 420 crores while minimum was Rs. 60000. There has been decline in CSR spending in 2012 as compared to 2011. During 2012-13, largest amount of CSR spending was reported for Lupin followed by Reliance Industries, Tata Steel, SBI and ICICI Bank. As per the analysis, an estimated amount of

Table No. 6 : Estimated CSR Spending by All BSE

Listed Companies in India

\begin{tabular}{|l|c|c|c|}
\hline \multicolumn{1}{|c|}{ Indicators } & $\mathbf{2 0 1 2}$ & $\mathbf{2 0 1 1}$ & $\mathbf{2 0 1 0}$ \\
\hline Total BSE listed companies & 5138 & 5138 & 5138 \\
\hline $\begin{array}{l}\text { Total Number of Qualifying } \\
\text { Companies in terms of Section } \\
\text { 135 Criteria }\end{array}$ & 1372 & 1409 & 1500 \\
\hline $\begin{array}{l}\text { Total Qualifying Companies } \\
\text { with Profit After Tax }>0\end{array}$ & 1265 & 1312 & 1457 \\
\hline $\begin{array}{l}\text { Maximum Profit After Tax } \\
\text { (Rs. Crore) }\end{array}$ & 21000.1 & 25100.2 & 20300.7 \\
\hline Maximum CSR (Rs. Crore) & 420 & 502.0 & 406.0 \\
\hline $\begin{array}{l}\text { Minimum Profit After Tax } \\
\text { (Rs. Crore) }\end{array}$ & 0.3 & 0.37 & 0.14 \\
\hline Minimum CSR (Rs.) & 60000 & 74000 & 28000 \\
\hline $\begin{array}{l}\text { Median Profit After Tax } \\
\text { (Rs. Crore) }\end{array}$ & 27.7 & 30.4 & 33.0 \\
\hline Minimum CSR (Rs.) & 5540000 & 6080000 & 6610000 \\
\hline
\end{tabular}

Source: IGIDR, 2015 
Rs. 8343.9 crore would have been spent on CSR activities by these companies based on their net profit amount for 2012. The CSR Rules are also applied to unlisted companies; the amount could be about Rs. 10,000 crore per year. Other estimates suggest total annual CSR spending to around $\$ 3$ billion. However, these estimates are relatively small in relation with the total government spending on social programs. The analysis reveals that the CSR spending by the median firm having a turnover of Rs. 33 crore, is about Rs. 55 lakhs per year. Companies like Reliance and ONGC, would have to spend upwards of about Rs. 400 crore every year towards CSR activities. This amount is likely to increase every year as the net profit of these companies is likely to increase.

Indian Institute of Corporate Affairs has estimated that at least 6000 companies will have to adopt new CSR rules. It is apparent that 2 per cent mandate is likely to impact a wide range of Indian companies. During 2013-2014, larger CSR spending companies were reported to be Reliance Industries, ICICI Bank, Tata Steel, Sesa Sterlite and TCS. However, this spending as percentage of net profits was reported higher in case of Tata Motors (5.17 per cent) followed by Tata Steel (3.31 per cent), Reliance Industries (3.24 per cent) and Adani Enterprises (3.08 per cent) (Table No 7).

Table No. 7 : CSR Expenditure of India's Large Private Sector Companies

\begin{tabular}{|l|r|c|}
\hline \multicolumn{1}{|c|}{ Company } & $\begin{array}{c}\text { 2013-14 CSR } \\
\text { Spending } \\
\text { (\$ Million) }\end{array}$ & $\begin{array}{c}\text { CSR Spending as } \\
\text { Percentage of Net } \\
\text { Profit }\end{array}$ \\
\hline Reliance Industries & 119.88 & 3.24 \\
\hline Tata Motors & 2.84 & 5.17 \\
\hline Tata Steel & 34.7 & 3.31 \\
\hline Essar Oil & N/A & N/A \\
\hline Hindalco Industries & 5.28 & 1.81 \\
\hline Bharathi Airtel & 6.62 & 1.46 \\
\hline Larsen and Toubro & 12.6 & 1.40 \\
\hline
\end{tabular}




\begin{tabular}{|l|r|c|}
\hline TCS & 15.06 & 0.48 \\
\hline ICICI Bank & 80.59 & 2.00 \\
\hline Mahindra and Mahindra & 5.35 & 0.87 \\
\hline SesaSterlite & 28.32 & 1.40 \\
\hline Adani Enterprises & 0.9 & 3.08 \\
\hline Infosys & 1.47 & 0.09 \\
\hline JSW Steel & 4.42 & 2.00 \\
\hline HDFC Bank & 11.52 & 0.83 \\
\hline
\end{tabular}

Source: CSIS, 2015.

Although some studies (Singh and Aggarwal 2013) have studied the types of CSR activities undertaken by Indian companies, By the year 2013, many firms had disclosed the activities undertaken by them, they could not disclosed the amount they spent on each activity. It has been observed that most of the firms have undertaken CSR expenditure on welfare of rural communities, especially around their areas of operation. As compared with developed countries where CSR activities are undertaken mainly in the area of environment, in India it is mainly undertaken in the social sector. After community development, education including skill development attracts the largest share of CSR expenditure. Health is also a major area where firms like to invest. The table gives an industry-wise breakup of the major CSR activities undertaken by each industry (Table No. 8).

Table No. 8 : Industry-wise Segregation of Major CSR Activities Undertaken by Firms in 2012-13.

\begin{tabular}{|l|c|c|c|c|c|}
\hline \multicolumn{1}{|c|}{ Industry } & Health & Education & $\begin{array}{c}\text { Community } \\
\text { Development } \\
/ \text { Rural } \\
\text { Development }\end{array}$ & $\begin{array}{c}\text { Environ } \\
\text { ment }\end{array}$ & Total \\
\hline Oil and Gas & $23.50 \%$ & $35.29 \%$ & $29.41 \%$ & $11.76 \%$ & $100 \%$ \\
\hline Automobile & $40.00 \%$ & $10.00 \%$ & $40.00 \%$ & $10.00 \%$ & $100 \%$ \\
\hline $\begin{array}{l}\text { Consumer } \\
\text { Durables }\end{array}$ & $24.76 \%$ & $21.34 \%$ & $15.25 \%$ & $28.75 \%$ & $100 \%$ \\
\hline Iron \& Steel & $35.29 \%$ & $23.53 \%$ & $35.29 \%$ & $5.88 \%$ & $100 \%$ \\
\hline
\end{tabular}




\begin{tabular}{|l|c|c|c|c|c|}
\hline $\begin{array}{l}\text { Banking \& } \\
\text { Financial } \\
\text { Services }\end{array}$ & $8.57 \%$ & $20.00 \%$ & $48.57 \%$ & $35 \%$ & $100 \%$ \\
\hline Power & $10.00 \%$ & $10.00 \%$ & $45.00 \%$ & $35.00 \%$ & $100 \%$ \\
\hline Infrastructure & $8.35 \%$ & $30.55 \%$ & $44.44 \%$ & $16.66 \%$ & $100 \%$ \\
\hline Cement & $22.20 \%$ & $25.00 \%$ & $29.00 \%$ & $23.80 \%$ & $100 \%$ \\
\hline Paper \&Pulp & $19.90 \%$ & $24.10 \%$ & $18.00 \%$ & $38.00 \%$ & $100 \%$ \\
\hline $\begin{array}{l}\text { Pharmaceutic } \\
\text { al }\end{array}$ & $30.00 \%$ & $28.00 \%$ & $22.00 \%$ & $20.00 \%$ & $100 \%$ \\
\hline
\end{tabular}

Source: Calculated from the annual reports of the top 200 firms for the year 2012-13

Nearly one third of total CSR expenditure was reported on education in the last three years (till November30,2017) . The health and rural development sectors together accounted for just above one third of the overall funds of CSR. Expenditure on environment, animal welfare, gender equality and aged welfare constituted less than 10 percent of total CSR spending (Table No. 9).

Table No. 9 : CSR Spending in India

(As on November 30, 2017)

(Rs. Crore)

\begin{tabular}{|l|r|c|}
\hline \multicolumn{1}{|c|}{ Sector } & \multicolumn{1}{c|}{ Amount } & Percentage \\
\hline Education / Differently Abled & 9316.33 & 33.14 \\
\hline $\begin{array}{l}\text { Health/Hunger/Poverty and } \\
\text { Malnutrition/Sanitation }\end{array}$ & 7913.85 & 28.15 \\
\hline Rural Development & 2987.15 & 10.63 \\
\hline $\begin{array}{l}\text { Other Sectors (Benefits to Armed } \\
\text { Forces, etc.) }\end{array}$ & 2785.05 & 9.91 \\
\hline Environment, Animal Welfare, etc. & 2020.79 & 7.19 \\
\hline Gender Equality/Old Age Homes & 626.73 & 2.23 \\
\hline Prime Minister's National Relief Fund & 526.93 & 1.87 \\
\hline Swachch Bharat Kosh & 507.11 & 1.8 \\
\hline Heritage, Art and Culture & 278.16 & 0.99 \\
\hline
\end{tabular}




\begin{tabular}{|l|r|c|}
\hline Encourage Sports & 239.85 & 0.85 \\
\hline Slum Area Development & 116.64 & 0.41 \\
\hline Clean Ganga Fund & 60.13 & 0.21 \\
\hline Others & 732.91 & 2.61 \\
\hline Total & 28111.63 & 100.00 \\
\hline
\end{tabular}

Source: Lok Sabha Questions and Answers.

CSR budget for 2014-15 is shown in Table 10. According to the Indian Institute of Corporate Affairs (IICA), about Rs. 200 billion (roughly $\$ 3.2$ billion) could be unlocked from a pool of around 16,000 companies for CSR spending during 2014-15. However, most of the companies had contributed less than Rs. 5 millions in social investment in India ( Table No. 10).

Table No. 10 : CSR Budget in India

\begin{tabular}{|c|r|c|}
\hline CSR Budget (Rs. Millions) & Frequency & Percentage \\
\hline Upto Rs. 5 & 13346 & 83.12 \\
\hline Rs. 5-10 & 1196 & 7.45 \\
\hline Rs. 10-50 & 1186 & 7.34 \\
\hline Rs. 50-100 & 182 & 1.13 \\
\hline Rs. 100-200 & 79 & 0.49 \\
\hline Rs. 200-500 & 43 & 0.27 \\
\hline Rs. 500 and More & 25 & 0.16 \\
\hline Total & 16057 & 100.00 \\
\hline
\end{tabular}

Source: IICA, 2013

The CSR activities are being implemented through building network and collaboration with voluntary organizations, community based organizations and even directly providing support to community. The major target groups covered under CSR initiatives are poor, marginalized, deprived and backward population. The thematic issues of CSR initiatives are being decided by the mandate of 
corporate houses, companies and business enterprises however, it also depends on the demand from the community. There has been significant increase in the number of beneficiaries under CSR initiatives during last 3 years. The corporate houses and companies further revealed that they are concentrating their CSR activities in their operational area and also on the basis of demand generated by their stakeholders. Most of the organizations reported that they have separate allocation of funds or CSR corpus for implementation of CSR activities.

\section{Conclusion}

The external environment of business has undergone revolutionary changes which generated far-reaching impact on organizational performance and their management strategies. With globalization and liberalization of economy, issues like the changing desires and attitudes of customers, the requirement of government agencies, rapidly advancing technology, increasing cost of production, increased awareness towards environmental protection and sustainable development and rapidly changing political scenario have emerged as issues of importance which corporate sector cannot ignore. These issues affect the organizations and management intensively. The philosophy of 'Bottom of the Pyramid' advocated by Prof. Prahlad gained momentum in the context of changed business environment and social responsiveness of corporate houses. Milton Friedman viewed that business should produce goods and services efficiently and leave the solution of social problems to government, concerned organizations and individuals. However, Keith Davis is of the view that there is an iron law of responsibility which states that in the long-run those who do not use power in a manner that society considers responsible will tend to lose it. Thus, it was advocated by the management experts that business organizations must devote resources to socially desirable objectives besides making profits to maintain the confidence and support of its stakeholders and creditors.

CSR can generate values and create opportunities for corporate houses for enhancing their business performance and building strong relations with the stakeholders and community. The corporate houses 
may also explore new market opportunities besides maintaining the brand loyalty among their stakeholders. Therefore, CSR must be under pinned by a strong business case that links social and environmental responsibility with financial success. The CSR agenda in India is changing and beginning to follow global CSR trends. It is integrating CSR into core business processes, ensuring that CSR takes root in top management and assigning its responsibilities to corporate houses and business entities. For Indian companies, community development is very important since it paves the way for good relations with communities and also has an appreciable public relations effect. However, community development projects must be viewed critically since they lack transparency, the involvement of relevant authorities is lacking and community development may conceal malpractices or violations within a company.

\section{References}

Aupperle, K.E, Carroll, A.B \& Hatfield, J.D (1985) 'An Empirical Examination of the Relationship between Corporate Social Responsibility and Profitability', Academy of Management Journal, Vol 28, Issue 1, pp. 446-463

IGIDR (2015), Corporate Social Responsibility in India: An Effort to Bridge the Welfare Gap, Indira Gandhi Institute for Development Research, Bombay

MCA, (2000), Report of the Task Force on Corporate Excellence by the Ministry of Corporate Affairs, Ministry of Corporate Affairs, Government of India.

MCA, (2009), Corporate Social Responsibility Voluntary Guidelines ,2009 by the Ministry of Corporate Affairs, Government of India.

MCA, (2011), The National Voluntary Guidelines on Socio Economic and Environmental Responsibilities of Business, Ministry of Corporate Affairs, Government of India, New Delhi

MCA, (2013), Companies Act, 2013, Ministry of Corporate Affairs, Government of India, New Delhi.http://www.mca.gov.in/

MCA, (2014), CSR Circular, 2014, Ministry of Corporate Affairs, Government of India, New Delhi.http://www.mca.gov.in

MCA, (2014), CSR Rules, 2014, Ministry of Corporate Affairs, 
Government of India, New Delhi.http://www.mca.gov.in/Ministry/

Mirshak, R. and Jamali, D.(2007). Corporate Social Responsibility (CSR): Theory and Practice in a Developing Country Context, Journal of Business Ethics, -72 (3), 24362.

Nelling, E., \& Webb, E. (2009). Corporate social responsibility and financial performance: The "virtuous circle" revisited. Review of Quantitative Finance and Accounting, 32(2), 197-209.

Pinkston, T.S., \& Carroll, A.B. (1996). "A retrospective examination of CSR orientations: Have they changed?'Journal of Business Ethics, 15(2), 199-206.

Porter ME and Kramer MR (2002). "The Competitive Advantage of Corporate Philanthropy", Harvard Business Review, 80(12), 5668

Singh, R and Aggarwal, S (2013): "Corporate Social Responsibility Impact: Approach to measure social impact using CSR Impact Index", Working Paper Series No. 729, Indian Institute of Management Calcutta

WBCSD, (2001), Sustainability Through the Market - seven keys to success, World Business Council for Sustainable Development, 87. 